\title{
ANTIDEPRESSANTS IN SOCIAL ANXIETY DISORDER
}

\author{
Antonio E. Nardi
}

\begin{abstract}
Social anxiety disorder (SAD) is a marked and persistent fear of doing almost everything in front of people due to concerns about being judge by others. An up-to-date review is needed in order to reach a practical judgement of all psychopharmacological data. Case reports, open and double-blind trials with SAD were described and commented upon from a clinical point of view. The MEDLINE system was searched from 1975 to 2001. The references from the selected papers were also used as a source. MAOls (fenelzine, tranylcypromine), reversible monoamino oxidase-A inhibitors (moclobemide, brofaromine), SSRIs (paroxetine, sertraline, fluoxetine, fluvoxamine) and some other antidepressants (venlafaxine, nefazodone) have proven effective in several studies with various methodologies. The MAOIs have more serious adverse effects and the SSRIs have the best tolerance. SSRIs are efficacious and the first choice of treatment.
\end{abstract}

KEY WORDS: social anxiety disorder, social phobia, pharmacologic treatment.

\begin{abstract}
Antidepressivos no transtorno de ansiedade social
RESUMO - A fobia social é o medo acentuado e persistente patológico de comer, beber, tremer, enrubescer, falar, escrever, enfim, de agir de forma ridícula ou inadequada na presença de outras pessoas. Muitos estudos clínicos têm sido conduzidos com o objetivo de se obter um tratamento eficaz. É necessária uma revisão atualizada para alcançar um julgamento clínico de todos os dados com antidepressivos. 0 sistema MEDLINE foi pesquisado no período de 1975 a 2001. As referências dos artigos consultados também foram utilizadas com fonte. Antidepressivos inibidores da monoamino oxidase (IMAO) (fenelzine, tanilcipromina), inibidores reversíveis da monoamino oxidase tipo-A (RIMA) (moclobemida, brofaromina), antidepressivos inibidores seletivos de serotonina (ISRS) (paroxetina, sertralina, fluoxetina, fluvoxamina) e alguns outros (venlafaxina, nefazodone) têm demonstrado eficácia em inúmeros estudos com diferentes metodologias. Os ISRS são o grupo mais estudado com metodologia duplo-cega, com melhores resultados e com boa tolerância, sendo a primeira escolha no tratamento.
\end{abstract}

PALAVRAS-CHAVE: fobia social, transtorno de ansiedade social, tratamento farmacológico.

The primary characteristic of social anxiety disor$\operatorname{der}(\mathrm{SAD})$ or social phobia ${ }^{1,2}$ is a persistent and excessive fear of being criticized and judged in performance or social interactive situations. SAD is a new expression for social phobia emphasizing the anxiety symptoms and not just the avoidance ${ }^{1}$. People who suffer from SAD have the feeling that they will be judged negatively in situations where they have to perform activities while being observed, with fear of feeling embarrassed or of being humiliated. They are even more afraid or embarrassed when someone notices their symptoms of anxiety ${ }^{2}$. The fear of these situations and the anxiety provoked when they must be confronted is so intense that it makes the individual avoid public activities where such exposition may occur. This is an inadequate answer to cer- tain stimuli, as a result of the presence somatic symptoms and their intensity and duration.

Pacients may report symptoms that are common to anxiety, like palpitations, tremblings, sweating, muscular tension, mouth dryness, nausea, diarrhoea or headache. However, some pacients complain mainly of exaggerated fear and self-criticism, which prevents them from interacting normally. There are two subtypes of SAD: the circumscribed one (symptoms in just one specific situation) and the generalized (symptoms in all social situations). This clinical difference has some therapeutic implications. The treatment of choice may be the association of psychopharmacotherapy and psychotherapy².

We describe below the main clinical-phamacological studies with antidepressants in SAD. The reAssociate Professor, Institute of Psychiatry, Federal University of Rio de Janeiro RJ, Brazil. This research was supported by the Brazilian
Council for Scientific and Technological Development (CNPq), Grant 300500/93-9.

Received 8 March 2001, received in final form 25 April 2001. Accepted 9 May 2001.

Dr. Antonio E. Nardi - R. Visconde de Pirajá, 407/702 - 22410-003 Rio de Janeiro RJ - Brasil. FAX: 55215236839.

E-mail: aenardi@novanet.com.br 
Table 1. Irreversible inhibitors of monoamine oxidase (MAOI) in social anxiety disorder.

\begin{tabular}{|c|c|c|c|c|}
\hline Year & Authors & Treatment & $\mathrm{N}$ & Result \\
\hline 1986 & Liebowitz et al. ${ }^{3}$ & Phenelzine & 11 & $\begin{array}{l}\text { Open trial. } 7 \text { months of treatment. } \\
7 \text { patients with good response. }\end{array}$ \\
\hline 1988 & Versiani et al. ${ }^{4}$ & Tranylcypromine & 29 & $\begin{array}{l}\text { Open trial. One year of treatment. } \\
62 \% \text { good response and } 17 \% \text { moderate response. }\end{array}$ \\
\hline 1992 & Liebowitz et al. ${ }^{5}$ & $\begin{array}{l}\text { Phenelzine } \\
\text { Atenolol } \\
\text { Placebo }\end{array}$ & 74 & $\begin{array}{l}\text { Double-blind. Response to phenelzine was } \\
\text { significantly better than response to atenolol and placebo. } \\
66 \% \text { good response to phenelzine. }\end{array}$ \\
\hline 1992 & Versiani et al. ${ }^{6}$ & $\begin{array}{l}\text { Phenelzine } \\
\text { Moclobemide } \\
\text { Placebo }\end{array}$ & 78 & $\begin{array}{l}\text { Double-blind. Phenelzine and moclobemide } \\
\text { better than placebo. }\end{array}$ \\
\hline
\end{tabular}

vision was made through the MEDLINE system, with the key words: SAD, social phobia, antidepressant, psychopharmacology, benzodiazepines, tricyclic, monoamine oxidase inhibitor, selective serotonine reuptake inhibitors, treatment. The period of the research was between 1975 and 2001. The references of the selected works were used as another source of bibliographic consultation.

\section{Monoamine Oxidase Inhibitors (MAOIs)}

In the 80s clinical studies with homogeneous groups of social phobics were carried out. The efficacy of the MAOIs, such as tranylcypromine and phenelzine, in the treatment of SAD patients without comorbid depression, has been proved by open ${ }^{3,4}$ and double-blind studies ${ }^{5,6}$ (Table 1).

The first open study ${ }^{3}$ used phenelzine in 11 SAD patients. A big improvement was verified in 7 cases treated with 45 and $60 \mathrm{mg} /$ day doses for 7 months. In another open study ${ }^{4}$ tranylcypromine was tested in 29 patients. The treatment duration was 1 year, with 40 and $60 \mathrm{mg} /$ day doses. After the exclusion of 3 patients that abandoned the treatment in the beginning, a big improvement could be observed in $62 \%$ and a moderate improvement in $17 \%$ of the sample. The common side effects noticed in the studie ${ }^{3,4}$ were: orthostatic hypotension, insomnia, decreased libido, fatigue, nausea, diarrhoea, irritability and increase in psychomotor activity. These side effects had a tendency to disappear with the maintenance of the treatment and adjustment of the dose. The studies also demonstrated that accentuated degrees of improvement could be observed only after three months of treatment. This observation strenghts the clinical impression that studies using the double-blind method must have a minimal duration of 4 months; distinguishing SAD patients from patients with depression or panic disorder.

The first double-blind study with patients with $S A D^{5}$ compared phenezine and atenolol with placebo in the treatment of 74 patients with SAD. The average dose was $76 \mathrm{mg} /$ day for phenelzine and $98 \mathrm{mg} /$ day for atenolol.
During the 16 week treatment, about 2/3 of the patients treated with phenelzine had significant improvement, whereas less than $1 / 3$ had the same improvement in the groups treated with atenolol and placebo. The patients treated with MAOI, in spite of dietetic restrictions and high risk of serious side effects, had an important reduction in social anxiety and avoidance, performing more comfortably their social and professional activities. It was observed that patients suffering from generalized SAD had better results with phenelzine.

Moclobemide, a reversible inhibitor of MAO - A (RIMA), appeared as a hope in the treatment of SAD. Its profile of side effects and its safety in the interaction with food and other pharmacs brought an incentive to the research in the area ${ }^{7}$. However, the results are conflicting about its efficacy (Table 2).

The first double-blind study with moclobemide ${ }^{6}$ compared it with placebo and phenelzine. Moclobemide presented intermediary results ( $78 \%$ improvement) in the first 8 weeks, the same as the phenelzine (more than $80 \%$ improvement) in 16 weeks. Both drugs were significantly superior to the placebo in all mensurations. The maximum dose of moclobemide was of $600 \mathrm{mg} / \mathrm{day}$, and of phenelzine $90 \mathrm{mg} /$ day. Moclobemide was greatly superior to the fenelzine regarding tolerance of side effects.

A negative result was observed 8 in a double-blind study with placebo. 77 SAD patients were treated with moclobemide or placebo after demonstrating no response to a week with placebo treatment. The patients were treated for 8 weeks, and to the ones that had any small improvement another 8 weeks of treatment were offered. It could not be observed any difference between the two groups, with only $7(17,5 \%)$ patients improving in the moclobemide group against $5(13,5 \%)$ in the placebo group. In this trial there was a very low response to moclobemide and to placebo.

Moclobemide was also analyzed in a long open, naturalistic and introspective study 9.93 patients suffering from generalized and circumscribe SAD with and different comorbidities were treated with moclobemide for 2 years. The average dose was $712 \mathrm{mg} /$ day. 59 patients showed 
Table 2. Reversible inhibitors of monoamine oxidase - A (RIMA) in social anxiety disorder.

\begin{tabular}{|c|c|c|c|c|}
\hline Year & Authors & Treatment & $\mathrm{N}$ & Result \\
\hline 1992 & Van Vilet et al. ${ }^{12}$ & $\begin{array}{l}\text { Brofaromine } \\
\text { Placebo }\end{array}$ & 30 & $\begin{array}{l}\text { Response to brofaromine was } \\
\text { significantly better than the placebo one. }\end{array}$ \\
\hline 1992 & Versiani et al. ${ }^{6}$ & $\begin{array}{l}\text { Moclobemide } \\
\text { Fenelzine } \\
\text { Placebo }\end{array}$ & 78 & $\begin{array}{l}\text { Response to moclobemide was comparable to the } \\
\text { phenelzine and significantly better than the } \\
\text { response to placebo. }\end{array}$ \\
\hline 1995 & Fahlen et al. ${ }^{13}$ & $\begin{array}{l}\text { Brofaromine } \\
\text { Placebo }\end{array}$ & 77 & $\begin{array}{l}\text { Response to brofaromine was significantly better } \\
\text { than the response to placebo. }\end{array}$ \\
\hline 1997 & Noyes et al. ${ }^{10}$ & $\begin{array}{l}\text { Moclobemide } \\
\text { Placebo }\end{array}$ & 503 & $\begin{array}{l}\text { Responses to moclobemide and placebo were comparable; } \\
\text { significant dose response was shown with } 900 \mathrm{mg} \\
\text { moclobemide. }\end{array}$ \\
\hline 1997 & Versiani et al. ${ }^{9}$ & Moclobemide & 93 & $\begin{array}{l}\text { Ultra-long term open trial. Moclobemide was efficacious. } \\
\text { Every } 2 \text { years the drug was washed-out and the symptoms } \\
\text { returned. Mean dose: } 712 \mathrm{mg} \text { per day. }\end{array}$ \\
\hline 1997 & Lott et al. ${ }^{14}$ & $\begin{array}{l}\text { Brofaromine } \\
\text { Placebo }\end{array}$ & 102 & Dose up to $150 \mathrm{mg} /$ day. Brofaromine superior to placebo. \\
\hline 1997 & International Multicenter ${ }^{11}$ & $\begin{array}{l}\text { Moclobemide } \\
\text { Placebo }\end{array}$ & 578 & $\begin{array}{l}\text { Response to } 600 \mathrm{mg} \text { moclobemide was significantly better } \\
\text { than the response to placebo. }\end{array}$ \\
\hline 1998 & Schneier et al. ${ }^{8}$ & $\begin{array}{l}\text { Moclobemide } \\
\text { Placebo }\end{array}$ & 77 & $\begin{array}{l}\text { Response to moclobemide was significantly better than } \\
\text { the response to placebo; both groups had low } \\
\text { levels of response. }\end{array}$ \\
\hline
\end{tabular}

significant symptomatological improvement and completed the 2 years treatment. After a minimum period of one month without the drug, $88 \%$ of the patients showed the symptoms again and were treated for 2 more years with the same therapeutic response. A follow-up after the 6 to 24 months of treatment demonstrated that $15,8 \%$ were without any kind of treatment, $28,1 \%$ were using moclobemide again, $10,6 \%$ were using other medicines and $8,8 \%$ were in psychotherapy. The patients that did not improve with moclobemide presented almost always alcohol abuse $(36,9 \%)$ and severe or moderate SAD. Alcohol abuse was a strong predictor of absence of therapeutic response.

An American multicenter study with moclobemide ${ }^{10}$ observed a poor drug and a high placebo response. After a week using placebo, the patients were randomically alocated in 6 groups: placebo or doses of 75, 150, 300, 600 or $900 \mathrm{mg} /$ day of moclobemide. After 12 weeks it was observed a similar answer from all the groups, with the good response of $35 \%$ of the patients using $900 \mathrm{mg} /$ day of moclobemide and 33\% using placebo.

In another international multicentric study with moclobemide $^{11}$, a moderate opposite result was observed. 578 patients with SAD, after using placebo for a week, were treated for 12 weeks with moclobemide $300 \mathrm{mg} / \mathrm{day}$ or $600 \mathrm{mg} /$ day or placebo. It was reported a clear relation dose-therapeutic response, with the $600 \mathrm{mg} /$ day dose of moclobemide being significantly more efficient than the other two groups. The smaller dose of moclobemide $300 \mathrm{mg} /$ day was also better than the placebo in all men- surations, but did not attain statistical significance. The most commom side effect was insomnia.

Another RIMA, brofaromine, has been showing good therapeutic results ${ }^{12-14}$ (Table 2 ). The first double-blind trial with brofaromine ${ }^{12}$ in 30 patients with SAD was a 12-week placebo controlled design. A significant improvement was seen in $80 \%$ of the brofaromine group (150mg daily) but not on placebo. Most common side effect was middle sleep disturbance. During a follow-up period of 12 weeks a further improvement was found in patients treated with brofaromine. In another double-blind trial ${ }^{13}, 77$ patients were randomized to treatment with brofaromine $(n=37)$ or placebo $(n=40)$ for 12 weeks. In the brofaromine group, $78 \%$ of the patients scored much or very much improved on the Clinical Global Impression scale, compared with $23 \%$ in the placebo group. The drug group improved further during 9-month follow-up treatment period, whereas $60 \%$ of the placebo responders who continued long-term treatment relapsed. The most frequent side effects in the brofaromine group were sleep disturbances, dry mouth and nausea.

Brofaromine was also analyzed in an another doubleblind study with placebo ${ }^{14}$. After one week of placebo, 102 patients were treated for 10 weeks ( 50 with placebo and 52 with brofaromine). Brofaromine started with a 50 $\mathrm{mg} /$ day dose and was progressively increased up to 150 $\mathrm{mg} /$ day according to therapeutic response. Brofaromine was significantly superior to placebo in the utilized evaluation methods. 14 patients using brofaromine dropped 
Table 3. Double-blind trials with SSRIs in social anxiety disorder.

\begin{tabular}{|c|c|c|c|c|}
\hline Year & Authors & Treatment & $\mathrm{N}$ & Result \\
\hline 1994 & Van Vliet et al. ${ }^{27}$ & $\begin{array}{l}\text { Fluvoxamine } \\
\text { Placebo }\end{array}$ & 30 & $\begin{array}{l}\text { 12-week treatment. Statistically significant effect for } \\
\text { anxiety; no significant difference for phobic avoidance. }\end{array}$ \\
\hline 1995 & Katzelnick et al. ${ }^{24}$ & $\begin{array}{l}\text { Sertraline } \\
\text { Placebo }\end{array}$ & 12 & $\begin{array}{l}\text { Crossover design. 10-week treatment each drug. } \\
\text { Significant difference to sertraline period. }\end{array}$ \\
\hline 1996 & Stein et al. ${ }^{32}$ & $\begin{array}{l}\text { Paroxetine } \\
\text { Placebo }\end{array}$ & 36 & $\begin{array}{l}11 \text {-week open-label study, } 12 \text {-week double-blind } \\
\text { treatment. Relapse rate higher for patients randomized } \\
\text { to placebo. }\end{array}$ \\
\hline 1998 & Stein et al..$^{33}$ & $\begin{array}{l}\text { Paroxetine } \\
\text { Placebo }\end{array}$ & 187 & $\begin{array}{l}\text { 12-week treatment. Paroxetine significantly } \\
\text { better than placebo. }\end{array}$ \\
\hline 1999 & Stein et al. ${ }^{28}$ & $\begin{array}{l}\text { Fluvoxamine } \\
\text { Placebo }\end{array}$ & 92 & $\begin{array}{l}12 \text {-week treatment. Fluvoxamine significantly } \\
\text { better than placebo. }\end{array}$ \\
\hline 2001 & Van Amering et al. ${ }^{25}$ & $\begin{array}{l}\text { Sertraline } \\
\text { Placebo }\end{array}$ & 204 & $\begin{array}{l}\text { 20-week treatment. Sertraline significantly } \\
\text { better than placebo. }\end{array}$ \\
\hline
\end{tabular}

from the study precociously, 11 due to adverse effects. The most commom adverse effects were insomnia, dizziness, dry mouth, anorexia and shaking.

The classic MAOIs are drugs that affect several neurotransmission systems. They have strong noradrenergic, serotoninergic and dopaminergic actions and serious side effects $^{3,4,7}$. This can explain their efficacy but also their very low tolerance.

Despite their proved efficacy in clinical controlled studies against placebo, the MAOIs, especially phenelzine or its congeneric tranylcypromine, cannot be considered as first choice treatments for SAD. They may induce serious hypertension crisis, with irreversible effects because of interactions with sympathomimetic substances.

It was said, about the treatment of panic disorder ${ }^{7}$, that these medicaments, in spite of being more efficient, are not the most recommended. In the case of SAD this should be even more stressed. Despite being very incapacitating, SAD is chronic and the symptoms come to surface only in determined situations. Using these drugs would submit the patient to the risks of serious side effects for many years, even during the assymptomatic periods. The most worrisome accidents are endogenous or spontaneous hypertensive crisis that happens with no apparent reason. One likely explanation this kind of hypertensive crisis is the possibility that bacterial metabolism in the bowels produces tyramine $e^{4,7}$.

\section{Tricyclic Antidepressants}

Clormipramine has some efficacious report ${ }^{15}$ and also as inefficient in 6 individuals with $\mathrm{SAD}^{4}$. It was a case report of the 6 poor response patients. The state of the patients became worse due to light shaking in the hands, induced by the tricyclic. The patients were treated with doses between 175 and 250 mg/day for 3 months. After this period of time, the patients were treated with tranylcypromine, showing good results.
Imipramine was evaluated in an open study ${ }^{16}$ with a sample of 15 patients treated for 8 weeks. Only 9 patients finished the treatment, and all the ones that dropped out, did it because of the side effects. Among the patients that finished the treatment the therapeutic response was very small, about $20 \%$.

\section{Nefazodone}

The antidepressive nefazodone is a serotonin-reuptake inhibitor and a 5-HT2 receptor agonist. An open study ${ }^{17}$ observed a positive response in 3 among 5 patients with $S A D$, and 3 individuals had comorbidity with dyshymic disorder. Another open clinical study was carried out ${ }^{18}$ with a sample of 23 patients with generalized SAD. The duration of the treatment was 12 weeks. 21 patients finished the treatment, and $16(69,6 \%)$ had a good or moderate response.

\section{Venlafaxine}

Venlafaxine is an antidepressant drug that inhibits noradrenaline and serotonin reuptake. It was described as potentially efficient in an open study ${ }^{19}$ with 9 patients, with 8 of them being considered refractory to serotoninspecific reuptake inhibitors (SSRIs). A larger trial ${ }^{20}$ aimed to evaluate the clinical response to venlafaxine in 12 patients who were non-responders to selective serotonin reuptake inhibitors. The duration of the study was 15 weeks using open flexible doses ranging from 112.5 to $187.5 \mathrm{mg} /$ day. Venlafaxine significantly reduced the avoidant behaviour the specific sociophobic aspects. The main side-effects being nausea, headache and anxiety.

\section{Serotonin-Specific Reuptake Inhibitors (SSRIs)}

SSRIs have been largely used in SAD (Table 3). Fluoxetine was tested in 16 social phobia patients with an open method for 12 weeks $^{21}$. The treatment started with 20 $\mathrm{mg} /$ day and was increased according to the efficacy and 
tolerance each 4 weeks. Various scales of self and observer evaluation were used. 13 patients finished the treatment, and 10 were considered as showing therapeutical response. A later onset and shorther duration of the disorder characterized the patients who improved.

Sertraline was efficient in $16(80 \%)$ patients in a sample of 22 with SAD, during 12 weeks with an open method ${ }^{22}$. It was also described as efficient ${ }^{23}$ in doses of up to 200 $\mathrm{mg} /$ day during 12 weeks with 11 patients. Only 7 patients finished the study, and 5 responded favorably, with an average dose of $170 \mathrm{mg} /$ day. The 4 patients that abandoned the study did it because of adverse effects and loss of the interest to continue with the treatment. Sertraline was analyzed in $\mathrm{SAD}^{24}$ with a doube-blind method with cross-over in 12 patients. Initially they were treated for 10 weeks with sertraline in doses between 50 and $200 \mathrm{mg} /$ day. Consecutivelly, they were treated for 10 weeks with placebo. The results were statistically favorable to sertraline. It is interesting that the patients were analyzed by examinators and by computer analyzed self-evaluation scales. There was no difference between the two evaluation methods, but the patients preferred the evaluation done by the computer.

Van Amering et al. ${ }^{25}$ evaluated sertraline vs. placebo in 204 generalized SAD patients for a 20-week doubleblind study. The dosing was flexible up to a maximum of $2000 \mathrm{mg} /$ day. Significantly more the 134 patients given sertraline $(n=71[53 \%])$ than of the 69 patients receiving placebo $(n=20[29 \%])$ were considered responders according to their CGI improvement scores at the end of treatment.

A positive result was observed in a case report with 3 patients taking citalopram ${ }^{26}$. All the 3 patients had their state improved after more than 8 weeks of treatment.

In another trial double-blind trial ${ }^{27}$, fluvoxamine (150 mg daily) was compared to placebo in 30 patients during a 12-week period. A substantial improvement was observed in $7(46 \%)$ patients on fluvoxamine and in $1(7 \%)$ on placebo. Statistically significant effects were seen on measures of SAD treated with fluvoxamine compared to placebo. The level of phobic avoidance decreased also but the difference at endpoint between fluvoxamine and placebo failed to reach statistical significance.

The fluvoxamine ${ }^{28}$ was analyzed with a double-blind method with placebo in 92 social phobic patients treated for 12 weeks. The generalized subtype was present in $91,3 \%$ of the patients. The average dose of fluvoxamine was $202 \mathrm{mg} /$ day. There was little response $(42,9 \%)$ but it was significantly superior to the placebo $(22,7 \%)$.

An open label trial of fluvoxamine ${ }^{29}$ was conducted to evaluate its efficacy safety in SAD and to assess physiological changes that may accompany treatment. 15 nondepressed patients entered the sudy. 10 patients completed an active 6 week treatment period. There were 3 drop-out due to side effects: drowsiness $(n=2)$ and nausea $(n=1)$. Clinical benefits were still evident at a short follow-up 1 week after drug discontinuation. Neither physi- ological effects nor plasma drug concentration correlated with clinical change. Fluvoxamine appeared to be effective and well tolarated in completers.

The first report of clinical observation with the efficacy of paroxetine against $S A D^{30}$ stimulated the realization of controlled studies. Paroxetine was utilized in 18 generalized SAD patients treated ${ }^{31}$ with an open method for 12 weeks. All the patients finished the research; and $15(83.3 \%)$ responded favorably. Another open study with paroxetine ${ }^{32}$ for 11 weeks analyzed 36 patients with generalized SAD. The average dose was $47.9 \% \mathrm{mg} /$ day. 23 (77\%) patients were considered as showing a significant symptomatological improvement. At the end of this initial stage, 16 patients were randomized for more 12 weeks of double-blind treatment with paroxetine on a fixed dose or placebo. Only 1 patient showed a return of the symptoms in the paroxetine group, against 5 in the placebo group.

A large North American multicenter trial with paroxetine in $S A D^{33}$ compared it to placebo in a 12-week double-blind condition. 183 patients were randomly selected and the daily dosage of paroxetine was $20 \mathrm{mg}$ with increases of $10 \mathrm{mg} /$ day weekly (flexible dosing to a maximum of $50 \mathrm{mg} /$ day). $55.0 \%$ of 91 persons taking paroxetine and $23.9 \%$ of 92 persons taking placebo were much or very much improved at the end of treatment.

\section{CONCLUSION}

The antidepressants seem to be the group of choice for SAD patients. When we take into account the controlled studies, the first choice of treatment for SAD will be the SSRIs antidepressants. They have been widely studied and have shown good therapeutic results and tolerance.

\section{REFERENCES}

1. American Psychiatric Association. Diagnostic and statistical manual for mental disorders. 4.Ed. DSM-IV. Washington: American Psychiatric Press, 1994.

2. Liebowitz MR, Gorman JM, Fyer AJ, Klein DF. Social phobia: review of a negleted anxiety disorder. Arch Gen Psychiatry 1985;42:729-736.

3. Liebowitz MR, Fyer AJ, Gorman JM, Campeas R, Lewin AL. Phenelzine in social phobia. J Clin Psychopharm 1986;6:93-98.

4. Versiani M, Mundim FD, Nardi AE, Liebowitz MR. Tranylcypromine in social phobia. J Clin Psychopharm 1988;8:279-283.

5. Liebowitz MR, Schneier F, Campeas R, et al. Phenelzine vs. atenolol in social phobia: a placebo controlled comparison. Arch Gen Psychiatry 1992;49:290-300.

6. Versiani M, Nardi AE, Mundim FD, Liebowitz MR, Amrein R. Pharmacotherapy of social phobia: a controlled study with moclobemide and phenelzine. Br J Psychiatry 1992;161:353-360.

7. Versiani M, Nardi AE, Figueira I, Stabl M. Tolerability of moclobemide a new reversible inhibitor of monoamine oxidase. A comparison with other antidepressants and placebo. Acta Psychiatr Scand 1990;360 (Suppl):24-28

8. Schneier FR, Goetz D, Campeas R, Fallon B, Marshall R, Liebowitz MR. Placebo-controlled trial of moclobemide in social phobia. Br J Psychiatry 1998;172:70-77.

9. Versiani M, Nardi AE, Mundim FD, Pinto S, Saboya E, Kovacs R. The long term treatment of social phobia with moclobemide. Int Clin Psychopharmacol 1996;11(suppl 3):83-88. 
10. Noyes R Jr, Moroz G, Davidson JR, et al. Moclobemide in social phobia: a controlled dose-response trial. J Clin Psychopharmacol 1997; 17:247-254.

11. International Multicenter Clinical Trial Group on Moclobemide in Social Phobia. Moclobemide in social phobia: a double-blind, placebocontrolled clinical study. Eur Arch Psychiatry Clin Neurosci 1997;247:71-80.

12. van Vliet IM, der Boer J, Westenberg HGM. Psychopharmacological treatment of social phobia: clinical and biochemical effects of brofaromine, a selective MAO-A onhibitor. Eur Neuropsychopharm 1992;2:21-29.

13. Fahlen T, Nilsson HL, Borg K, Humble M, Pauli U. Social phobia: the clinical efficacy and tolerability of the monoamine oxidase-A and serotonin uptake inhibitor brofaromine: a double-blind placebo-controlled study. Acta Psychiatr Scand 1995,92:351-358.

14. Lott M, Greist JH, Jefferson JW, et al. Brofaromine for social phobia: a multicenter, placebo-controlled double-blind. J Clin Psychopharmacol 1997; $17: 255-260$

15. Beaumont G. A large open multicenter trial of clomipramine in the management of phobic disorders. J Med Res 1977;5:116-123.

16. Simpson HB, Schneier FR, Campeas RB, et al. Imipramine in the treatment of social phobia. J Clin Psychopharm 1998;18:132-135.

17. Worthington JJ, Zucker BG, Fones CS, Otto MW, Pollack MH. Nefazodone for social phobia: a clinical case series. Depress Anxiety 1998;8:131-133.

18. Van Ameringen M, Mancini C, Oakman JM. Nefazodone in social phobia. J Clin Psychiatry 1999;60:96-100.

19. Kelsey JE. Venlafaxine in social phobia. Psychopharm Bull 1995;31: 767-771

20. Altamura AC, Piolo R, Vitto M, Mannu P. Venlafaxine in social phobia: a study in selective serotonin reuptake inhibitor non-responders. Int Clin Psychopharmacol 1999;14:239-245.

21. Van Ameringen M, Mancini C, Streiner DL. Fluoxetine efficacy in social phobia. J Clin Psychiatry 1993;54:27-32.
22. Van Ameringen M, Mancini C, Streiner D. Sertraline in social phobia. J Affect Disord 1994;31:141-145.

23. Munjack DJ, Flowers C, Eagan TV. Sertraline in social phobia. Anxiety 1994;1:196-198.

24. Katzelnick DJ, Kobac KA, Greist JH, Jefferson JW, Mantle JM, Serlin RC. Sertraline for social phobia: a double-blind, placebo-controlled crossover study. Am J Psychiatry 1995;152:1368-1371.

25. Van Ameringen MA, Lane RM, Walker JR, et al. Sertraline treatment of generalized social phobia: a 20-week, double-blind, placebo-controlled study. Am J Psychiatry 2001;158:275-281.

26. Lepola U, Koponen H, Leinonen E. Citalopram in the treatment of social phobia: a report of three cases. Pharmacopsychiatry 1994;27:186188.

27. Van Vliet IM, den Boer JA, Westenberg HG. Psychopharmacological treatment of social phobia: a double-blind placebo controlled study with fluvoxamine. Psychopharmacology (Berl) 1994;115:128-134.

28. Stein MB, Fyer AJ, Davidson JR, Pollack MH, Wiita B. Fluvoxamine treatment of social phobia (social anxiety disorder): a double-blind, placebo-controlled study. Am J Psychiatry 1999;156:756-760.

29. DeVane CL, Ware MR, Emmanuel NP, et al. Evaluation of the efficacy, safety and physiological effects of fluvoxamine in social phobia. Int Clin Psychopharmacol 1999;14:345-351.

30. Ringold AL . Paroxetine efficacy in social phobia. J Clin Psychiatry 1994;55: 363-364.

31. Mancini C, Ameringen MV. Paroxetine in social phobia. J Clin Psychiatry 1996;57:519-522.

32. Stein MB, Chartier MJ, Hazen AL, et al. Paroxetine in the treatment of generalized social phobia: open-label treatment and double-blind placebo-controlled discontinuation. J Clin Psychopharmacol 1996;16:218222.

33. Stein MB, Liebowitz MR, Lydiard RB, Pitts CD, Bushnell W, Gergel I. Paroxetine treatment of generalized social phobia (social anxiety disorder): a randomized controlled trial. JAMA 1998;280:708-713. 